\title{
Friendly Guns: Power, Play, and Choice in Preschool
}

\author{
Kortney Sherbine
}

Kortney Sherbine is an assistant professor in the School of Teacher Education and Leadership at Utah State University. Her research examines teacher identity, literacies, and children's encounters with popular culture. Her work has appeared in the Journal of Early Childhood Literacy, the Journal of Language and Literacy Education, and Policy Futures in Education, among other journals and edited volumes. She is a former elementary grades teacher. Email: kortney.sherbine@usu.edu

This paper examines the power relations that emerged during an eight-week study of an afterschool program in a Montessori preschool. Drawing from a theoretical assemblage that engages Foucault's theory of biopower and Bennett's conceptualization of thing power, I analyze the intra-actions between the human and more-than-human and consider how children's bodies were disciplined to do and be certain things during a time of day when critical discourse analysis of ethnographic data details the ways in which certain intra-actions normalized some children's ways of knowing, being, doing, and playing while marginalizing others. I conclude by attending to the potential of children's relationships with popular culture in early childhood classrooms.

Key words: childhood; popular culture; Montessori; power; Foucault children could choose their play activities. A

Snack time has finished and the children slowly clean up their areas around the table. They discard their trash, put lunchboxes away, and retrieve damp cloths to wipe down the table. Almost simultaneously, Henry and Annie begin to sing under their breaths: We will, we will, rock you. We will, we will, rock you. Moments later, the teacher reaches for the stereo and turns up the volume, drowning out the children's voices with Tchaikovsky's 1812 Overture.

This brief vignette emerged from field notes compiled over the course of an eight-week study of a (Montessori) afterschool program. I bracket Montessori intentionally as the afterschool program existed in a liminal space between the preschool where it was housed, which was heavily influenced by the philosophies of Maria Montessori, and a space that was more open to children's intentions, personal experiences, and preferences. That is, the afterschool program was one where children had access to materials that were not part of the Montessori curriculum and were permitted, to an extent, to engage in fantasy play, which was oftentimes inspired by-or at least integrated-ideas from popular culture. At the time of the study, I was interested in young children's encounters with popular culture and the ways in which popular culture texts and materials permeated their play and conversation. Further, I was interested in responses to that play and conversation in a setting that was built on philosophies of teaching and learning that did not necessarily embrace popular culture as an appropriate part of the early childhood curriculum. In this paper, I focus on the children's play with one another and the relationships between and among the human and more-than-human in this afterschool program. In particular, I attend to the entanglements of power between the children, teachers, and materiality of popular culture, which seemed to highlight the ambiguity of the afterschool program as one that was both influenced-and not-by Montessori philosophies.

\section{Popular culture and Montessori education}

Children's encounters with popular culture have long been a source of agitation and concern for adults as notions of what counts as appropriate permeate early childhood settings. Much of this concern emerges from romanticized 
perceptions of childhood as a time of innocence, when children should be protected from capitalist consumer culture and images of sex and violence, and is tied to a dichotomous distinction between what is considered "high culture" and involves things like the classics and the canon, and "low culture," or the inferior culture of the people (Fiske, 1992; Nespor, 1997; Sherbine, 2017; Storey, 2018). In the classroom, popular culture texts and materials are often considered a distraction from an early childhood curriculum that "features play using more concrete play materials, such as wooden blocks, paint, and modeling clay" (Henward, 2015, p. 208). Despite adults' concerns, however, children's encounters with their everyday culture often include popular culture things and, frequently, those things are brought to school-Montessori schools included-on their bodies in the forms of clothing, lunchboxes and backpacks, toys, and ideas for stories to be shared and (re)composed with one another (Alvermann \& Xu, 2003; Buckingham \& Sefton-Green, 1994; Dyson, 1997, 2003; Hagood, Alvermann, \& HeronHruby, 2010).

Maria Montessori $(1964,1965,1974)$ shared strong opinions about the play that emerges around children's encounters with cultural texts that involve something other than those affiliated with "high culture." The fantasy play that often emerges alongside popular culture does not coincide with Montessori's belief that children belong "to a people for whom the delights of the mind are to be found in the great works of art, and the civilizing constructions of science, and in those products of the higher imagination which represent the environment in which the intelligence of our child is destined to form itself" (Montessori, 1965, p. 256). Cultural texts that emerge outside the great works of art were not considered by Montessori to contribute to the intelligent development of the child. Further, Montessori believed play to be a natural characteristic (O'Donnell, 2013), though she also believed that a child's play should be grounded in reality and should aid in the child's development as "through play, [the child] brings perfection to himself" (p. 111). Lillard and Taggart (2018) wrote, "Montessori teachers use children's fantasy play behaviors as clues to how they might help connect children to what is real" (p. 3). In sum, the kind of play that often emerges amidst children's encounters with popular culture is negated by Montessori philosophies, in favour of play that is connected to reality and that enables the child to develop into a particular kind of person.

After describing The Mountain Montessori School (names of people and places are pseudonyms) where this study took place, I detail how I went about composing data during my time as a participant observer in the afterschool program. Then, I describe the entanglements of the afterschool program and engage with a theoretical assemblage that considers appropriation and power in the relationships between the human and more-than-human. In doing so, I consider the ways in which power functioned to normalize certain ways of be[hav]ing in the afterschool program.

\section{The Mountain Montessori School: The Garden Room}

The Mountain Montessori School (MMS) was situated in a small college town in the northeastern United States. Accredited by the National Association for the Education of Young Children and Keystone Stars, the school was opened in 1993. In 2000, the director purchased the facility where the preschool was located at the time of this study, a light green split-level house with a sprawling yard and expansive interior. There were 45 children, ages 3 through 5, enrolled in the preschool and approximately 20 of those stayed for the afterschool program, which began at 2:30 each afternoon and was housed primarily in the Garden Room of the school.

The Garden Room was a multipurpose room of sorts. The walls were lined with bookshelves, which displayed writing and drawing tools, paints, musical instruments, and other assorted materials. There was a block centre against one wall and an area in one corner with overstuffed chairs and bookshelves that was designated for reading. The dramatic play area was in another corner. There was one large table in the room where I sat with children as we 
drew pictures and played with Play-Doh. A large green rug covered the floor in the wide-open centre of the room.

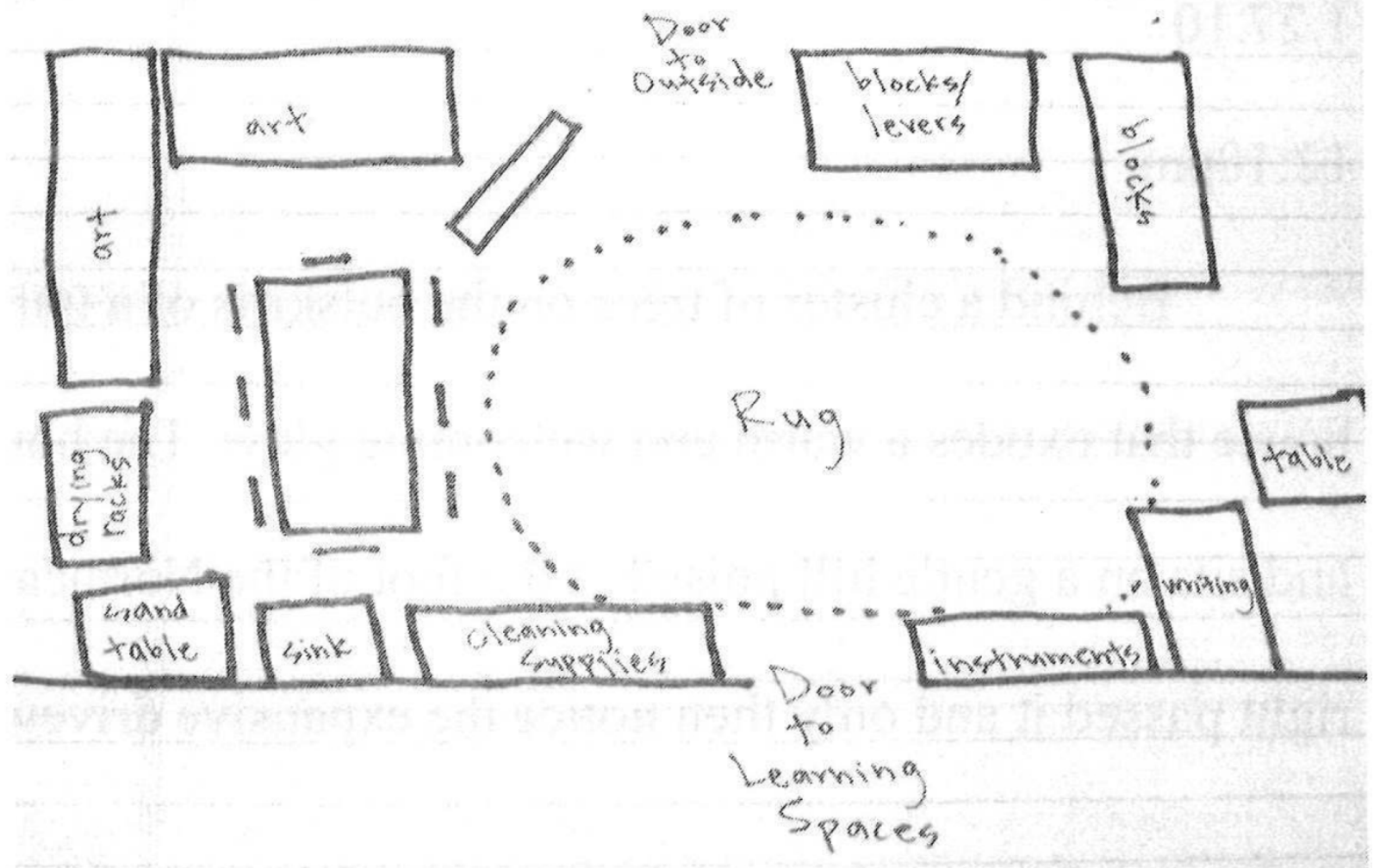

Figure 1. My sketch of the Garden Room. 


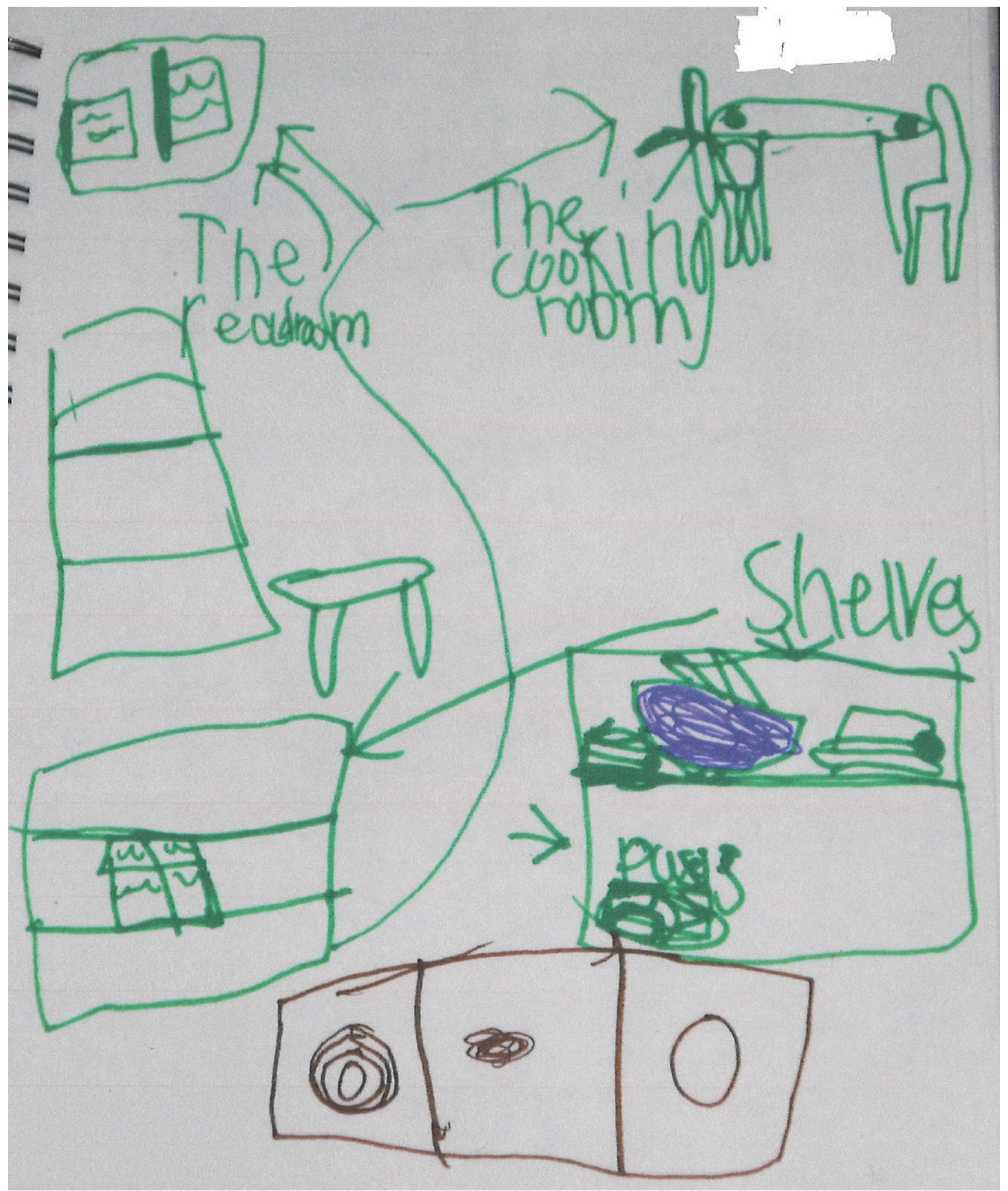

Figure 2. Annie's sketch of the Garden Room.

Soon after my arrival on Wednesday afternoons, I sat on the green rug with the children, listening as the school's director shared picture books with the group. Following a read-aloud, half of the group retreated to the upstairs rooms for rest time while others stayed in the Garden Room playing with materials and completing art projects 
until they left for the day. I stayed in the Garden Room, too, and engaged with the children while they built structures with LEGOs and transformed the dramatic play area into a restaurant, a grocery store, and a bank. I sat with children at the art table while they used Crayola markers and scrap pieces of paper to draw pictures for themselves, their teachers, and their family members. The Garden Room was a unique space at MMS because many of the materials available for the children's play were not part of the Montessori curriculum, unlike other spaces in the school that were designed with the philosophies of Maria Montessori in mind and where materials could not be used unless a teacher had first demonstrated how to do so (Lillard, p. 2013).

\section{Methods of inquiry}

I became acquainted with the director of MMS through our shared graduate coursework. Upon learning of my interest in children's encounters with popular culture, she invited me to visit and subsequently study the afterschool program at MMS. She had recognized the way popular culture permeated the children's play and was interested in thinking more about those relationships with me. Employing ethnographic research methods, I spent approximately three hours each week over the course of eight weeks as a participant observer in the Garden Room at MMS. Drawing on Corsaro's (2003) ethnographic inquiries alongside young children, I engaged with the children and things while they played and created in various centres of the room in hopes that I might be able to "suspend my adult perspective ... and consider things from a kid's point of view" (p. 39). I built ships with LEGOs and constructed veterinary hospitals for sick plastic animals with Magna-Tiles. I did not intervene when conflict arose between children, and I did not offer redirection if a child was not following the directives offered by the staff members. Further, I always asked for permission before joining the children's play, and I told them I might jot notes so that I could remember things from our time together. Gaining children's consent for me to document their experiences and to be part of those experiences in more direct ways was a critical piece of my approach to conducting ethical research alongside the children.

My goal was to be as accessible to the children as I could be with the intention of understanding the entanglements of relationships in the afterschool program from their perspectives, ever mindful of my position as an adult researcher, whose notebook and digital recorder presented me as someone from the outside who was interested in what the children said, how they played, and how they intra-acted with one another and their teachers. Wolcott (2005) alluded to this mindfulness and suggested that there is the potential in participatory research to be "agonizingly self-conscious" (p. 89) about being in the field. Uncertainty is an inevitable part of relational research that involves following the lead of another without knowing exactly what will be encountered.

\section{Participant observation}

As I embraced this inevitable uncertainty, I jotted fieldnotes as I played and listened alongside the children and more-than-human things. Following Geertz's (1973) suggestion to employ thick description, I began to process the elements of the afterschool program's culture through expanded field notes in order that I might examine the ways in which children's play, language, and the Montessori philosophy became entangled. A participant-observer in the Garden Room, I was positioned to experience the activities of the afterschool program as both an insider and outsider, and so, drawing from Wolcott's (2005) and Eisner's (1998) approaches, I engaged in self-reflection as I expanded my notes, attending to my "mood, personal reactions, [and] random thoughts" (Wolcott, 2005, p. 93) that emerged during each visit. This reflection was particularly crucial given the ways in which my own personal philosophies about childhood and learning differed from Montessori philosophies (e.g., I find children's encounters with popular culture to be highly intriguing and tend to welcome play and conversation that builds on their experiences with these texts) and the extent to which moments of cognitive dissonance arose in the field. 


\section{Interviews}

I also conducted informal interviews as I drew pictures of My Little Pony with Eliza at the art table and played alongside other children in different areas of the Garden Room. As Tammivaara and Enright (1986) wrote, interviews with children often are "taken up with children literally playing with items in the setting and figuratively playing with the questions and answers that are given” (p. 230).

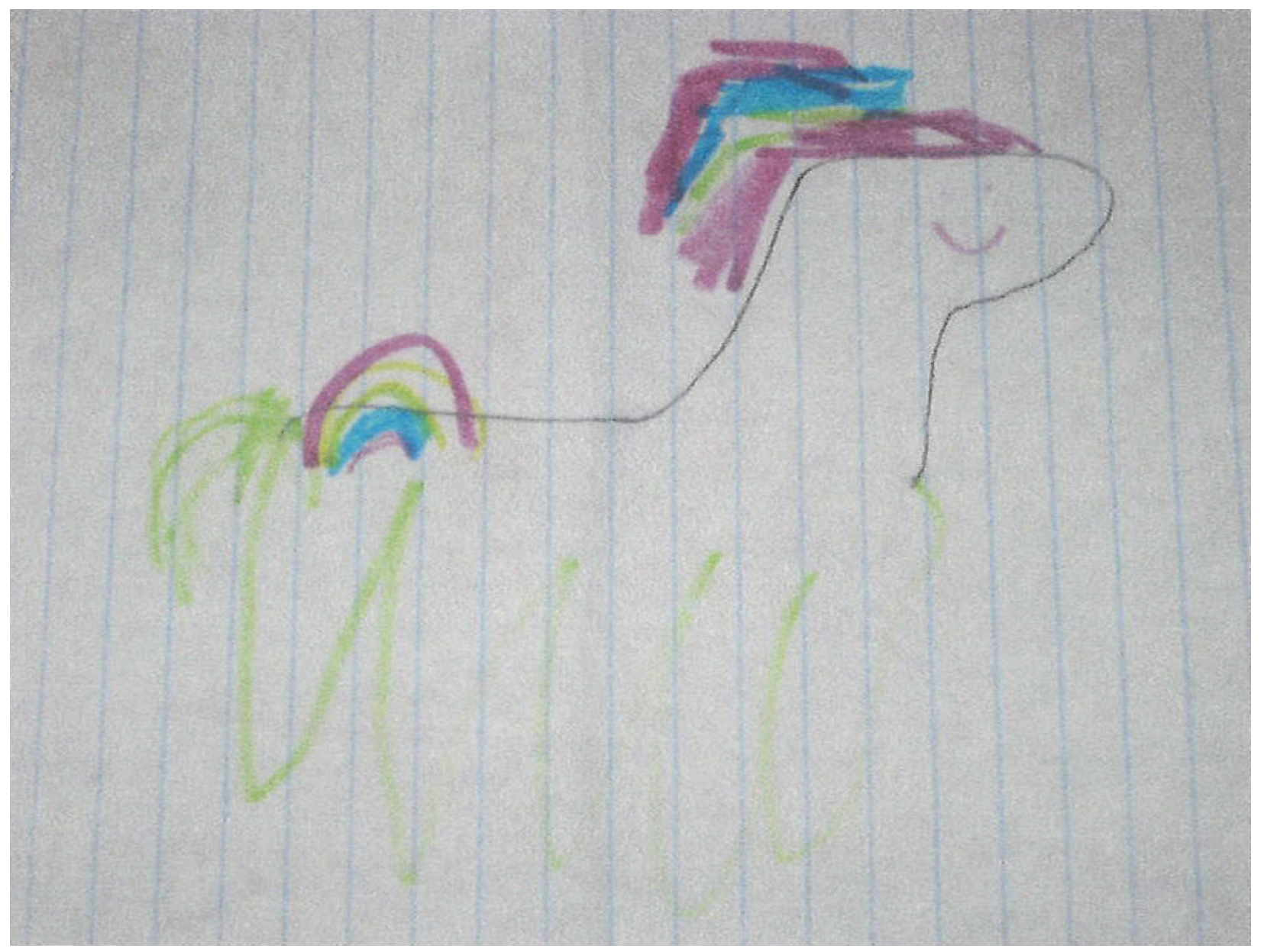

Figure 3. Eliza's drawing of My Little Pony with a cutie mark.

As my time at MMS drew to a close, I engaged the school's director in a formal interview. This allowed me to clarify-or not-my observations and interpretations of the ways in which the children, teachers, and materials constructed the culture of the afterschool program. My questions facilitated a conversation that offered the director the flexibility to "talk on [her] own terms" (Hammersley \& Atkinson, 2007, p. 110) and so our discussion included her interpretations of Maria Montessori's philosophies, particularly related to popular culture, and how that philosophy manifested in the afterschool program. Polkinghorne (1995) suggested that such clarification or triangulation creates opportunities to consider multiple realities, in this case, of the children, teachers, and morethan-human things in the afterschool program, in an effort to understand the culture of the community from many different perspectives. 


\section{Critical discourse and multimodal discourse analyses}

After compiling expanded field notes and transcripts, I engaged in critical discourse analysis (CDA), which allowed me to consider threads of power within the social actions of discourse. Walshaw (2007) wrote that CDA allows for an investigation of "how language functions, in a very strategic manner, to fashion subjectivity" (p. 44). CDA as I employed it here is not limited to an analysis of spoken language or, as Gee (1996) described, as little d discourse. Rather, CDA attends to big $D$ discourse, which involves both language and additional meaning-making practices that produce particular ways of constructing and experiencing a social reality. These additional meaning-making and identity-development practices are often multimodal in that they integrate multiple semiotic resources such as music, visual images, sound, and objects (Jewitt, 2017). Employing multimodal discourse analysis alongside CDA enabled me to avoid theorizing about language as “an isolated process" (O'Halloran, 2004, p. 1) and to consider the children's and teacher's encounters with bodies, multimodal texts, and materials.

After composing vignettes from my expanded field notes, I attended to the entanglements of bodies and objects and the ways in which encounters with and responses to popular culture materials also strategically functioned to produce particular subjectivities. In this way, I analyzed the data for how language and encounters with materials in the afterschool program positioned the children and adults. I examined conversations, artifacts, and intraactions to "locate, define, and regulate people in different ways" (Walshaw, 2007, p. 45). Attending to the process for CDA outlined by MacNaughton (1998), I looked for ways in which the children and adults were categorized and how meanings of these categories were constructed through social practices. In doing so, I considered the ways in which some children benefitted from the employment of particular discourses while others did not.

\section{Theoretical entanglements}

A number of theories are helpful in considering the human and more-than-human encounters in the MMS afterschool program. I draw primarily from Foucault's (2003) notion of biopower to consider the ways children's play and storytelling were at times denigrated in the name of maintaining a particular kind of culture in the Garden Room. Further, I employ the Bakhtinian (1981) concept of appropriation as I consider how language functioned to create space for children's creative improvisations while also normalizing some behaviours while marginalizing others. Finally, Bennett's (2010) conceptualization of thing power is useful in considering the generative nature of the relationships between children and the materials associated with popular culture. The theoretical assemblage of biopower-appropriation-thing-power enables me to engage with data in ways that attend to numerous possibilities of what might have been emerging in the relationships between bodies and things as the children, teachers, and more-than-human objects constructed the culture of the afterschool program. In analyzing the data through this theoretical assemblage, I attend to the complexities of entanglements of bodies, language, and objects in the Garden Room.

\section{Biopower}

Poststructuralist thinkers recognize discourse as inextricably linked to the functions of power relations. As Walshaw (2007) wrote, "power relations are an integral part of our personal and public lives. Always in tension, they are exactly the stuff that knits us all together" (p. 68). Foucault (1977) understood power to be neither positive nor negative; it is opportunistic, so its effects on individuals and populations vary depending on the context. Power is also productive in that it "allows bodies, gestures, discourses, and desires to be constituted as something individual" (p. 30). That is, power circulates through, between, and around individuals—and objects—and works through techniques of discipline and normalization (Foucault, 1977, 1978). 
Foucault (1977) described biopower as "the numerous and diverse techniques for achieving the subjugation of bodies and the control of populations" (p. 140). Biopower accounts for the ways in which minds and bodies are shaped by the discourses of ideologies in an effort to create a certain type of subject in the MMS afterschool program (Boldt, 2001; Foucault, 1978). Considerations of biopower alongside the data foster analysis of how the children were affected by disciplinary power and the ways in which children self-monitored and subjugated themselves to the discourses around them.

Embedded within biopower are the many mechanisms and techniques of discipline. Not always overt or coercive, disciplinary techniques include the organization of bodies, souls, space, materials, and time (Foucault, 1977). Discipline is a means by which bodies become members of an efficient machine, a machine in which "each pupil, each level, and each moment, if correctly combined, [are] permanently utilized in the general process of teaching" (p. 165). Disciplinary power permeates every aspect of society; we accept it because it suggests that some level of normal or acceptable existence is attainable. Walshaw (2007) elaborated that disciplinary power "makes us want to conform and comply ... without knowing it, we make sure that what we do, think, and say is in line with what is expected of us" (p. 129). Drawing on these notions of power, I analyze the ways in which children's encounters with popular culture in the MMS afterschool program were normalized and marginalized.

\section{Appropriation}

Bakhtin (1981) suggested that our words are not our own because they carry with them the meanings of those who used them before us, the meanings of those with whom we speak, and the constructed meanings within dialogue itself. He wrote that, "in all areas of life and ideological activity, our speech is filled to overflowing with other people's words, which are transmitted with highly varied degrees of accuracy and impartiality" (p. 337).

Language is purposeful and productive; it is employed to construct meanings and to take up subject positions. Children appropriate words, images, gestures and actions in order to "create situated meanings and fashion identities for particular purposes" (Nespor, 1997, p. 185), and teachers who espouse Montessori philosophies dictate particular ways of being and learning in relation to materials. Considerations of appropriation allow for analyses of both children's conversation and fantasy play as they create connections between their realities and their imaginations, expanding the possibilities of what is possible in the stories they compose and embody and the teachers' redirections of those connections toward behaviour more aligned with their images of childhood.

\section{Thing power}

Bennett's (2010) theory of thing power emerges from the posthumanist turn in educational research, which attends to the entanglements of humans and objects (Barad, 2007; Lenz Taguchi, 2010; Sherbine, 2018). Hers is part of a larger philosophical project which seeks to disrupt the hierarchical position of human over the rest of the world, instead focusing on the capacity of all things-human and more-than-human-to affect change and transformation in their relationships with one another. Thing power suggests that objects-the more-thanhuman-have the potential to create something new in their relationships with other objects and human bodies. These considerations are particularly significant in the context of Montessori philosophies, which carry specific expectations for the materials associated with the curriculum. Considerations of thing power alongside data from this study involves analyzing the relationships between the language, people, and the roles that objects play in the construction of identities, in how storylines play out, and in how discipline functions. 


\section{Power, play, and choice}

In this theoretical analysis of how power circulated and what it produced in the Garden Room, I focus on two elements that emerged: power in pop culture entanglements and disciplinary power and the child's body. These explications of power relations were considered in child $\leftrightarrow$ child, child $\leftrightarrow$ adult, and child $\leftrightarrow$ object intra-actions. The arrows I employ here denote what Foucault (2003) described as the "interplay" (p. 168) of power relationships and what Lenz Taguchi (2010) and others (Barad, 2007; Sherbine, 2018; Thiel, 2015) consider the "intra-actions" between bodies and materials. In other words, it is not a child acting on an adult or on an object; it is, rather, the mutual constitution of the child and adult and material that emerges in encounters.

\section{Power in popular culture entanglements}

As evidenced in the opening vignette, the children's entanglements with popular culture permeated their intraactions and play in the Garden Room. As Henry and Annie sang We Will Rock You, I asked Annie about the song. "I have it on my dad's phone," she said. "There's a white button and it turns green and then, We will, we will rock you. We will, we will rock you." Annie took great pleasure in entertaining me with a song that she knew other adults listened to. She positioned herself as artist-performer-singer who had captivated a guest in the Garden Room. Only moments before the singing and my conversation with Annie, the children had been eating their snacks as the sounds of Tchaikovsky filled the air. A teacher, who noticed my conversation with Annie as it was unfolding, walked to a nearby stereo and turned up the volume.

The juxtaposition of music was striking and served as a metaphor for the entanglements of discourses in the afterschool program. While many of the children appropriated from popular culture, many of the teachers appropriated their language and behaviours from Montessori philosophies, which promote an enlightened, peaceful, and disciplined child, one who should embrace the classical music of Tchaikovsky as it moves the child toward intelligence and true creativity more than the rock and roll of Queen (Montessori, 1964; Soundy, 2008).

Much like Henry and Annie, other children in the MMS afterschool program appropriated (Bakhtin, 1981) images, language, and storylines in their encounters with the materials, space, and with one another. Frequently, children physically embodied ideas from popular culture in their play, reifying storylines and characters and repurposing them in ways that allowed them to reposition themselves and each other in the power relations circulating through the Garden Room. Throughout the study in the afterschool program, children's entanglements with popular culture emerged in their play as teachers-to varying degrees-intervened and redirected the children toward activities that were more aligned with Montessori philosophies.

For example, one afternoon two children, Ron and William, and John, a high school student who cleaned MMS in the afternoons, engaged in prolonged play with LEGOs. Ron jumped up from his spot on the floor and clasping both hands together and keeping his arms straight, sliced through the air with an invisible light sabre. "You can't get me! I have a force field! You can't get me!" exclaimed William. Ron continued to wave the light sabre in the air for a few seconds and then returned to his work mat, where he resumed building his LEGO ship.

John sat next to the boys and dug around in the LEGO bin. "You know what, guys? I'm making friendly guns," he said.

"What are friendly guns?" asked William.

"You know, they're nice," John replied.

Ron employed the language of Star Wars battles to position himself and William in a good guy / bad guy binary. 
Nespor (1997) wrote that children appropriate from popular culture in order to explore subjectivities that might "position them favorably in their conflict" (p. 188). In this way, the language, gestures, and [invisible] objects from Star Wars functioned as tools that mediated the children's play and that made particular storylines possible. Ron could be a bad guy because "bad guy" was performed as part of recognizable Star Wars play and was removed from direct hostility with other children (I recognize that Ron could have actually been a good guy; that point was never made clear). The nature of good guy / bad guy play created an oppositional binary, but one that was required in order for the storylines to make sense to be expanded on by the children. As Paley (2004) wrote, children experience "emotional highs and lows of the hero and victim" (p. 15) in their storytelling and play. The quick embodiment of a light-sabre-wielding villain (or hero) enabled Ron and William to construct and experience a fleeting moment of nonviolent violence, domination, resistance, and recovery.

Brenda, a teacher and the school's director, explained that "warrior play," during which all players must feel safe, was permitted in the afterschool program, but John, with his mention of "friendly guns," effectively stopped the good guy / bad guy play, at least for a few moments. Perhaps John drew from Montessori's philosophies on friendship, which values the growth of a peaceful child, not one who would engage as a bad guy. Perhaps John was performing the role of "responsible adult" in his efforts to redirect Ron and William. He may have been drawing from the discourse of school violence, which often carries messages of zero tolerance for talk about-or play involving-violence in any form. It could have been that John was aware that parents were coming into the Garden Room to pick up their children and that he understood that some of them may have valued the encouragement to be a friendly child who refrains from violent play. Whatever the case, John's interjection about friendly guns clashed with the play in which Ron and William momentarily found great pleasure. The culture of the afterschool program was constructed by these clashes in discourse; as children found ways to use popular culture to negotiate their play and interactions, they did so alongside messages of what the "right kind" of play and conversation looked and sounded like.

Foucault (1978) wrote that power relations are "distributed in irregular fashion: the points, knots, or focuses of resistance are spread over time and space at varying densities, at times mobilizing groups or individuals in a definitive way, inflaming certain points of the body, certain moments in life, certain times of behavior" (p. 96). As a productive force, power influences individuals, groups, and objects as they negotiate their environments (Dyson, 1997; Foucault, 1978). Children understand the effects of power as they interact with one another, taking up identities for themselves that enable them to perform in certain ways. Ron and William were playing Star Wars in accordance with certain rules dictated by the series itself (e.g., the use of light sabres, the good guy / bad guy binary, the protective force field). How to engage in play the "right" way was determined by the discourse of Star Wars; the performers/players must do and say certain things. Resistance in power relations allows for room for improvisations and agency in children's play (Nespor, 1997). In these ways, power normalizes behaviour and determines whose actions are considered appropriate and whose actions marginalize them from the rest of the community (Dyson, 1997; Foucault, 1978; Luke, 1992).

\section{Popular culture encounters that count}

Children's knowledge and language about popular culture places them at a certain advantage among their peers, an advantage akin to what Bourdieu (2010) described as symbolic power. He wrote that "utterances are not only signs to be understood and deciphered; they are also signs of wealth, intended to be evaluated and appreciated, and signs of authority, intended to be believed or obeyed" (p. 480, italics in original). Brenda hinted at her own observations of the children's language about popular culture as she described how children with older siblings often had more experience with the media than other children and thus were in a better position to talk about such 
things. However, children who had less exposure to television, movies, or series such as My Little Pony or Star Wars found a way to slip into popular culture play. In describing the playful tendencies of the children with less exposure to popular culture, Brenda explained:

Some children don't have a fixed way of thinking and so some kids can come up with those things outside of the good guy / bad guy and sometimes those kids are our most creative kids, who are hearing snippets of this and snippets of that and make their own thing.

Brenda valued children's abilities to think beyond the images and storylines that appeared in various popular culture texts as they made their play "their own thing." This notion of "making" was an important component of the culture of the afterschool program. The children had a certain level of freedom to play with language, to find commonalities in their interests, to gently argue for their opinions, to extend existing storylines, to be heard, and to defend their preferences for certain things. There were limits on the children's agency, however, and as I describe below, teachers and children employed certain tactics to redirect other children who pushed the limit of what was acceptable.

\section{Disciplinary power and the child's body}

One afternoon, Teacher Mary sat with a few children at the art table. Sam sipped out of a Spiderman water bottle. Beth wore a High School Musical shirt. Henry's shoes bore the image of Iron Man, and Daphne wore ruby red slippers, like those worn by Dorothy from The Wizard of $\mathrm{Oz}$, on her feet. Annie shared with those around her that she would soon be visiting Disney World with her family. As Sam began to interject something about Disney World, Teacher Mary interrupted and asked Annie to tell the other children about her family. As quickly as it began, Annie's story about traveling to Disney World ended and she talked instead about her older brothers and sister and eventually her pet. Teacher Mary sat back and listened, allowing the children to engage in the conversation without further intervention.

In an interview, I asked Brenda about the timing of Teacher Mary's interjection, and she clarified the Montessori stance on Disney and popular culture more broadly.

Brenda: Most Montessori schools don't allow any logos on clothing. Clothing has to be plain and nonadvertising. Part of Montessori's approach to education was to love the fabric, to be more aesthetically appealing. So there would be a lot of wood, ceramic, plants in the environment. But you start into pop culture, it's plastic. It's red, blue, yellow, pink. Those colours overtake and those colours start to have gendered meaning, and Montessori was really against that.

Kortney: And so, where does Disney fit into all of that? I've heard the children speak briefly about Dis-

Brenda: We don't do Disney books. We encourage children to bring books from home, but we usually say, like Caldecott or children's literature. You know, a different genre. If a child brings a [Disney] book, we don't say, "Oh, that's bad. You have to take it back." We hold it up and show it, but we don't read it. So we're not promoting any kind of pop culture materials, but we're not having a total ban on clothing or toys, either.

Montessori philosophies that undoubtedly influenced the afterschool program at MMS disparaged popular culture as being unnatural or artificial and thus unsuitable (though somewhat tolerated) for the Garden Room. Could it be that it was not only Annie's naming of Disney World that prompted Mary to intervene? I argue that the thing power of the popular culture images and artifacts - the Spiderman water bottle, the High School Musical shirt, the Iron Man Shoes, and the ruby red slippers-that emerged within the assemblage of bodies around the table also 
influenced Teacher Mary to redirect Annie toward a more appropriate story to share. That is, it was not Annie's statement about Disney alone but the confluence of popular culture materials in their relation to the children and the teacher's expectations that prompted Teacher Mary to intervene.

Another example of disciplining the body in relation to children's fantasy play and popular culture emerged as Ron approached Brenda with an elaborate LEGO ship. Brenda, who was surrounded by other children playing with Play-Doh, engaged in the following conversation with Ron as he stood next to her and pushed his LEGO ship into her arm:

Ron: I'm here to kill you.

Brenda: Now why would you want to do that?

Ron: Your dog got on the computer and said you were going to kill me, so l'm going to kill you.

Brenda: Well, that's not possible! I don't have a dog. I only have thirteen cats!

Brynnan: Whoa! Thirteen cats!

Ron: [Appearing distracted, lowers his LEGO ship and picks up a piece of Play-Doh]

Brenda [to me]: See? Even the kids know how weird that is.

Ron positioned his teacher as being inferior, on the receiving end of his threats of violence, which accompanied his LEGO ship that quite literally applied pressure on Brenda's body. Brenda's response to Ron was one of resistance, albeit a resistance masked by questions expressing her own misunderstanding. As she responded to Ron, she modelled appropriate ways of participating in conversation and play. As Brenda's exchange with Ron suggests, the exercise of power is not a negative force but is productive in the sense that it disciplines children to interact with others in particular ways.

Foucault $(1977,1978)$ wrote extensively about the ways in which the body is disciplined to be and do certain things. Whereas punishment is often considered physical force that comes after an offence, discipline is a component of power that influences one's psyche. The following is from an interview with Brenda. She described the school's philosophy on discipline in relation to Beth, a 5-year-old who was accused of bullying other children in the afterschool program:

What we do in our classroom is have free choice time, and they love that. But when someone has behaviour issues, they lose their choice, and that's the term we use. We say, "Are you going to be able to make a good choice or are you going to lose your choices now?" So we decided as a staff about a week and a half ago that Beth's bullying just wasn't getting any better, so there have been a few times in the past few weeks that she's had to hold the hand of a teacher and go wherever the teacher went. And she was mortified. And that's all there is. There was no negative punishment whatsoever. It was just holding the teacher's hand and losing your freedom. And that's the most effective behaviour management l've ever seen.

Brenda did not consider having to hold a teacher's hand and follow her around as negative punishment, though Beth's resulting mortification suggests otherwise. Still, Brenda and the staff's attempts to redirect Beth to more appropriate interactions with her peers involved practices that were intended to shape her psyche, to guide future decisions she would make in her peer interactions. 


\section{Coding the body}

Foucault (1977) described the types of discipline Brenda described-holding the teacher's hand, following the teacher around, losing free choice time-as "coding the body" (p. 153). A subject is trained that there are appropriate ways to be and anything outside of that (e.g., bullying) is considered pathological or abnormal and in need of improvement. Coding the body and other mechanisms of discipline are ubiquitous in early childhood education (Jones, 2013; MacNaughton, 1998; Nespor, 1997). Montessori (1965) devoted portions of her entire method to discipline and wrote that discipline creates "a good child:"

The goodness he has conquered cannot be summed by up inertia-his goodness is now made up of action. As a matter of fact, good people are those who advance toward the good-the good which is made up of their own self-development and of external acts of order and usefulness. (pp. 352-353)

Techniques of discipline work to create a particular kind of child-a good child-who contributes to the construction and maintenance of the Montessori culture. Foucault's (2003) notion of biopower describes how, in order to maintain the ideal population, members of the classroom community are disciplined as subjects and producers of the classroom norm.

In the following vignette, an encounter between Ron, his peers, Teacher Pam, a paper cup, and a trash can demonstrates how biopower was enacted in the Garden Room through the assemblages of the human and morethan-human. Snack time was ending and children began to clean up their areas, a skill that is taught explicitly in the Montessori curriculum as a part of developing more independence (Montessori, 1964)

A paper cup flew through the air and landed on the shelf next to the trashcan. "Aw, man!" said Ron, dropping his arms from above his head. Immediately, Teacher Pam was next to him.

"Ron, what in the world? You will get up and throw that away the right way," she said.

Ron slowly got out of his chair and grabbed the cup and placed it in the trashcan.

"No, you will go back to your seat and show me that you can throw it away the way that you should."

Ron took the cup out of the trashcan, returned to his seat, sat down, then stood up, walked to the trashcan, and placed the cup inside.

The other children watched in silence until Beth spoke up: "And now he can't have a cup anymore!"

"That's right," Pam responded, "he can't until he remembers how we throw our cups away after snack time." She turned to face the group of children watching her. "We do not throw them through the air. We take them and put them in the trash."

It was clear from the reactions of both Teacher Pam and Beth that Ron's initial method of cleanup was atypical of, and unacceptable in, the MMS afterschool program. Pam's shift from referring to Ron as "you" and then "he" functioned simultaneously to dictate to Ron what he had done wrong, to distance Ron from the norms of the group, and to remind the other children of the expectations for cleanup time. Beth's linguistic contribution to the event further reified the established norms and identified consequences for acting outside of those norms. This language of subjectification (Walshaw, 2007) is another technique of disciplinary power, one that positions a child as aberrant whose behaviour in a particular moment and in a particular context alienates him from the rest of the population. 
Further, the cup and the trashcan-in relationship with Ron's embodiment of an NBA point guard's shooting motion and Pam's redirection-imbued a thing power that carried potential for play, disruption, and discipline at once. The cup-as-basketball and trash-can-as-basketball-hoop created with Ron an enactment of fantasy play that, if only momentarily, freed him from the routines of cleanup time toward something more visceral and playful. When the cup was relegated to trash and the trash can to a receptacle in their intra-actions with Ron, the teacher, and Beth, the objects reified the expectations of the afterschool program: routine, order, and usefulness.

\section{Conclusion}

In this paper, I described the many tensions between children, teachers, philosophies, and popular culture materials in a Montessori afterschool program. Drawing on Foucault's $(1977,2003)$ and Bennett's $(2010)$ conceptualizations of power, I engaged with expanded field notes and interview data to understand how and the extent to which children's encounters with popular culture were diminished. In doing so, I recounted how the culture of the afterschool program, with its ambiguity in terms of its relationships with Montessori philosophies and the availability of non-Montessori materials for play, was constructed through the intra-actions between bodies and materials in the Garden Room.

One limitation of this study involves the time I was able to spend at MMS. This study was limited to the afterschool program housed in the school, and though interviews with the school's director did offer useful background information as to Montessori philosophies and how they play out in curriculum and interactions, there might have been more of an opportunity to contextualize the afterschool program had I engaged in participant observation throughout the course of the school day. Further, I did not conduct formal interviews with teachers and other adults (e.g., John and Teacher Mary). While I can infer their intentions based on what I understand about Montessori philosophies and the context of the afterschool program, I recognize that their perspectives were not amplified in this work.

It is notable that the disciplinary tactics that emerged in the afterschool program at MMS are not unique to Montessori programs. Schools function, in many ways, to construct particular ways of acting, thinking, and being (Varenne \& McDermott, 1998). While the study highlighted in this paper focused on the relationships between Montessori philosophies as they were enacted at MMS in relation to children's play and talk with popular culture texts, what is sanctioned in many educational settings is often limited to that which can be assessed and quantified. Policies and routines are enacted to regulate children's behaviour and learning, and often these policies discount children's relationships with popular culture (Dyson, 2003; Nespor, 1997).

However, as Dyson (1997, 2003, 2016), Wohlwend (2009, 2011), and others (Alvermann et al., 1999; Marsh, 2006; Ranker, 2006; Sherbine, 2019; Williams, 2007) have described, popular culture texts in the classroom carry great potential for fostering children's development of critical literacy and playful identities. When teachers foster play and talk with popular culture, children have opportunities to plan, remix, revise, and improvise storylines from their favourite movies or television shows. Further, engaging with popular culture in the classroom through a permeable curriculum that "allows for the interplay between teachers' and children's language and experiences" (Dyson, 2016, p. 24) offers opportunities for teachers to collaborate with children about topics for exploration and inquiry. In doing so, children might engage in critical media literacy, which recognizes the pleasure that children take in their relationships with popular culture (Alvermann et al., 1999), while also making commercially driven texts "malleable and open to renegotiation" (Wohlwend, 2011, p. 111). What opportunities might be missed if teachers employ disciplinary power in ways that redirect play and conversation away from popular culture texts with which children are experimenting? 
This study contributes to research on the ways in which certain images of childhood permeate our intra-actions with children and the extent to which children are encouraged or dissuaded from particular activities and ways of being. Sorin (2005) suggested that constructions of who children are-the innocent child, the evil child, and the miniature adult, to name a few-inform what we think children are capable of and what we believe their potential to be. Power relations that function to reify particular notions of what counts as childhood impact what is allowable and, as in the afterschool program at MMS, have the potential to silence children's singing, fantasy play, storying, and embodiments.

My time playing, listening, and watching alongside the children, teachers, and materials at MMS served as a reminder that, despite the best intentions to create child-centered environments and opportunities for children, engrained beliefs and values about children can invariably create a hierarchy of what matters and what is worth time and attention in early childhood. The children's relationships with popular culture materials in tension with the Montessori teachers' philosophies of what belonged in the afterschool program composed an ambiguous and liminal space where children, teachers, and materials - in their relationships with one another-recognized the potential of popular culture to create, disrupt, challenge, and reinvent. 


\section{References}

Alvermann, D., Moon, J., \& Hagood, M. (1999). Popular culture in the classroom: Teaching and researching critical media literacy. National Reading Conference. https://doi.org/10.4324/9781315059327

Alvermann, D., \& Xu, S. (2003). Children's everyday literacies: Intersections of popular culture and language arts instruction. Language Arts, 81(2), 145-155.

Bakhtin, M. M. (1981). Discourse in the novel. In M. Holquist (Ed.), The dialogic imagination: Four essays (pp. 259-422). University of Texas Press.

Barad, K. (2007). Meeting the universe halfway: Quantum physics and the entanglement of matter and meaning. Duke University Press.

Bennett, J. (2010). Vibrant matter: A political ecology of things. Duke University Press.

Boldt, G. (2001). Failing bodies: Discipline and power in elementary classrooms. Journal of Curriculum Theorizing, Winter, 90-104.

Bourdieu, P. (2010). Language and symbolic power. In A. Jaworski \& N. Coupland (Eds.), The discourse reader (pp. 480-490). Routledge.

Buckingham, D., \& Sefton-Green, J. (1994). Cultural studies goes to school: Reading and teaching popular media. Taylor \& Francis.

Corsaro, W. A. (2003). We're friends right? Inside kids' culture. Joseph Henry Press.

Dyson, A. (1997). Writing superheroes: Contemporary childhood, popular culture, and classroom literacy. Teachers College Press.

Dyson, A. (2003). Brothers \& sisters learn to write: Popular literacies in childhood \& school cultures. Teachers College Press.

Dyson, A. (2016). Negotiating a permeable curriculum: On literacy, diversity, and the interplay of children's and teacher's worlds. Garn Press.

Eisner, E. (1998). The kind of schools we need: Personal essays. Heinemann.

Fiske, J. (1992). The cultural economy of fandom. In L. Lewis (Ed.), The adoring audience: Fan culture and popular media (pp. 30-49). Routledge.

Foucault, M. (1977). Discipline and punish: The birth of the prison. Vintage Books.

Foucault, M. (1978). The history of sexuality, volume 1: An introduction. Vintage Books.

Foucault, M. (2003). Society must be defended: Lectures at the College de France 1975-1976 (M. Bertani \& A. Fontana, Eds.). Picador.

Gee, J. (1996). Social linguistics and literacies: Ideology in discourse. RoutledgeFalmer.

Geertz, C. (1973). Thick description: Toward an interpretive theory of culture. In The Interpretation of cultures: Selected essays (pp. 3-30). Basic Books.

Hagood, M., Alvermann, D., \& Heron-Hruby, A. (2010). Bring it to class: Unpacking pop culture in literacy learning. Teachers College Press.

Hammersley, M., \& Atkinson, P. (2007). Ethnography: Principles in practice (3rd ed.). Routledge.

Henward, A. (2015). “She don’t know I got it. You ain’t gonna tell her, are you?" Pop culture as resistance in American preschools. Anthropology \& Education Quarterly, 46(3), 208-223. https://doi.org/10.1111/aeq.12103

Jewitt, C. (2017). The Routledge handbook of multimodal analysis. Routledge.

Jones, L. (2013). Children's encounters with things: Schooling the body. Qualitative inquiry, 19(8), 604-610. https://doi. org/10.11771077800413494348

Lenz Taguchi, H. (2010). Going beyond the theory/practice divide in early childhood education: Introducing an intra-active pedagogy. Routledge. 
Lillard, A. (2013). Playful learning and Montessori education. American Journal of Play, 5(2), 157-186. https://www.journalofplay.org/ sites/www.journalofplay.org/files/pdf-articles/5-2-article-play-learning-and-montessori-education_0.pdf

Lillard, A., \& Taggart, J. (2018). Pretend play and fantasy: What if Montessori was right? Child Development Perspectives, 0(0), 1-6. https://doi.org/10.1111/cdep.12314

Luke, A. (1992). The body literate: Discourse \& inscription in early literacy training. Linguistics \& Education, 4, 107-129. https://doi. org/10.1016/0898-5898(92)90021-N

MacNaughton, G. (1998). Improving gender equity “tools”: A case for discourse analysis. In N. Yelland (Ed.), Gender in early childhood (pp. 149-174). Routledge.

Marsh, J. (2006). Popular culture in the literacy curriculum: A Bourdieuan analysis. Reading Research Quarterly, 41(2), 160-174. https:// doi.org/10.1598/RRQ.41.2.1

Montessori, M. (1964). The Montessori method. Schocken Books.

Montessori, M. (1965). Spontaneous activity in education. Schocken Books.

Montessori, M. (1974). Education for a new world. Kalakshetra.

Nespor, J. (1997). Tangled up in school. Lawrence Erlbaum.

O’Donnell, M. (2013). Maria Montessori: A critical introduction to key themes and debates. Bloomsbury.

O’Halloran, K. (2004). Multimodal discourse analysis: Systemic functional perspectives. Bloomsbury.

Paley, V. (2004). A child's work: The importance of fantasy play. The University of Chicago Press.

Polkinghorne, D. (1995). Narrative configuration in qualitative analysis. Qualitative Studies in Education, 8(1), 5-23. https://doi. org/10.1080/0951839950080103

Ranker, J. (2006). "There's fire magic, electric magic, ice magic, or poison magic": The world of video games and Adrian's compositions about Gauntlet Legends. Language Arts, 84(1), 21-33. https://www.jstor.org/stable/41962160?seq=1

Sherbine, K. (2017). Popular culture. In K. Peppler (Ed.), The SAGE encyclopedia of out-of-school learning (pp. 604-606). SAGE.

Sherbine, K. (2018). Track Star + thing power: Be[com]ing in the literacy workshop. Journal of Early Childhood Literacy. https://doi. org/10.1177/1468798418777847

Sherbine, K. (2019). Wrestling with competency and everyday literacies in school. Journal of Language and Literacy Education, 15(2), 1-22. https://www.academia.edu/40983793/Sherbine_K_2019_Wrestling_with_competency_and_everyday_literacies_in school Journal of Language and Literacy Education $\begin{array}{llll}15 & 2 & 1 & 22\end{array}$

Sorin, R. (2005). Changing images of childhood: Reconceptualising early childhood practice. International Journal of Transitions in Childhood, 1, 12-22. https://www.researchgate.net/publication/228363878 Changing images of childhood Reconceptualising early childhood practice

Soundy, C. (2008). Young children's imaginative play: Is it valued in Montessori classrooms? Early Childhood Education Journal, 36(5), 381-383. https://link.springer.com/article/10.1007/s10643-008-0282-Z

Storey, J. (2018). Cultural theory and popular culture (8th ed.). Routledge.

Tammivaara, J., \& Enright, D. (1986). On eliciting information: Dialogues with child informants. Anthropology \& Education Quarterly, 17(4), 218-238. https://doi.org/10.1525/aeq.1986.17.4.04x0616r

Thiel, J. (2015). "Bumblebee's in trouble!” Embodied literacies during imaginative superhero play. Language Arts, 93(1), 38-49. https:// www.jstor.org/stable/24577556 
Varenne, H., \& McDermott, R. (1998). Successful failure: The school America builds. Westview Press.

Walshaw, M. (2007). Working with Foucault in education. Sense.

Williams, B. (2007). Action heroes and literate sidekicks: Literacy and identity in popular culture. Journal of Adolescent and Adult Literacy, 50(8), 880-885. https://doi.org/10.1598/JAAL.50.8.6

Wohlwend, K. (2009). Damsels in discourse: Girls consuming and producing identity texts through Disney princess play. Reading Research Quarterly, 44(1), 57-83. https://doi.org/10.1598/RRQ.44.1.3

Wohlwend, K. (2011). Playing their way into literacies: Reading, writing, and belonging in the early childhood classroom. Teachers College Press.

Wolcott, H. (2005). The art of fieldwork (2nd ed.). AltaMira Press. 